\title{
TOTAL CONTENT OF PHOSPHORUS IN SOME FINNISH SOILS
}

\author{
ArMi KaIla \\ University of Helsinki, Department of Agricultural Chemistry
}

Received March 12, 1963

The total content of phosphorus in a soil is of little value in assessing its phosphorus fertility. Yet, some conclusions may be drawn concerning the development of soils by comparing their contents of total phosphorus. The total content of phosphorus is also a proper basis for the studies on the phosphorus conditions in the soils.

In the 1930 's, in connection with the soil survey work, Aarnio $(2,3)$ and Kivinen (11) published a large number of data on the phosphorus content of Finnish mineral soils. Since these analyses were performed by digesting the samples with the mixture of nitric acid and hydrochloric acid, it is likely that these results are lower than the total content of phosphorus: the acid digestion does not completely deliver the phosphorus in the coarser mineral particles. More reliable results may be obtained by the fusion with sodium carbonate, the method which was employed by SALONEN (13) for a few soil samples, and later by the present writer $(4,9)$ on a larger material.

The phosphorus content of virgin peat soils has been studied by Kivinen (10) and KaILA $(6,7)$. There are less information of the total phosphorus content of cultivated peat soils and humus soils.

In the present paper, the total content of phosphorus in Finnish soils is discussed on the basis of the data collected in connection with the writer's various works.

\section{Material}

The present material consists of 670 soil samples from various parts of the country. Yet, it cannot be claimed to give a representative picture of the total phosphorus in our soils, since the samples were not collected according to the principles of a statistical survey. The mineral soils of South Finland and Central Finland 
are more abundantly represented than those of the other parts of the country. A large part of the samples of the virgin peat lands are from Northern Finland.

The distribution of the soil samples into various groups (Table 1) shows that there are not enough samples from virgin mineral soils for any reliable comparison. Because of the smallness of most of the groups of the different kind of soils, the

Table 1. Total $\mathrm{P}$ content in various kind of soils

\begin{tabular}{|c|c|c|c|c|}
\hline & & \multirow{2}{*}{$\begin{array}{c}\text { Number } \\
\text { of } \\
\text { samples }\end{array}$} & \multicolumn{2}{|c|}{ Total P ppm } \\
\hline & & & Range & Mean* \\
\hline \multicolumn{5}{|c|}{ Surface soils } \\
\hline \multicolumn{5}{|c|}{ Cultivated } \\
\hline & Sand and fine sand & 60 & $390-1690$ & $860 \pm 80$ \\
\hline & Loam and silt & 69 & $470-1750$ & $980 \pm 60$ \\
\hline & Clay & 92 & $540-1830$ & $1170 \pm 50$ \\
\hline & Humus and peat & 64 & $410-1990$ & $1190 \pm 100$ \\
\hline \multicolumn{5}{|l|}{ Virgin } \\
\hline & Sand and fine sand & 16 & $420-900$ & $600 \pm 70$ \\
\hline & Loam and silt & 5 & $440-1130$ & $880 \pm 350$ \\
\hline & Clay & 4 & $710-870$ & $790 \pm 120$ \\
\hline & Peat & 81 & $220-1500$ & $800 \pm 70$ \\
\hline \multicolumn{5}{|l|}{ Deeper layers } \\
\hline \multicolumn{5}{|c|}{ Cultivated } \\
\hline & Sand and fine sand & 25 & $170-840$ & $430 \pm 60$ \\
\hline & Loam and silt & 23 & $270-1040$ & $680 \pm 80$ \\
\hline & Clay & 46 & $420-1790$ & $750 \pm 60$ \\
\hline & Humus and peat & 27 & $570-1260$ & $910 \pm 70$ \\
\hline \multicolumn{5}{|l|}{ Virgin } \\
\hline & Sand and fine sand & 11 & $100-750$ & $480 \pm 150$ \\
\hline & Loam and silt & 6 & $430-800$ & $610 \pm 120$ \\
\hline & Clay & 14 & $440-1160$ & $790 \pm 110$ \\
\hline & Peat & 136 & $260-2350$ & $740 \pm 60$ \\
\hline
\end{tabular}

* with the confidence limits at the 5 per cent level

sand and fine sand soils were combined to represent all the soils containing less than 30 per cent of clay $(<0.002 \mathrm{~mm})$ and more than 50 per cent of material coarser than $0.02 \mathrm{~mm}$. The loam and silt soils with less than 30 per cent of clay and less than 50 per cent of the fine sand fraction form one group, and the clay group includes all the samples with more than 30 per cent of clay. The humus soils contain at least 8.8 per cent of organic carbon.

The samples of the surface soils were taken from the plough layer of the cultivated soils, or from the top layer down to $15 \mathrm{~cm}$ or $20 \mathrm{~cm}$ in the virgin soils. The 
samples of the "deeper layers» were collected from various layers between the depths of $20 \mathrm{~cm}$ and $70 \mathrm{~cm}$ in the mineral soils, and between the depths of $20 \mathrm{~cm}$ and $6 \mathrm{~m}$ in the peat soils.

\section{Analytical methods}

The total phosphorus content of the mineral soils and the humus soils was determined by the sodium carbonate fusion method (12), and that of the peat soils by a modification of the Kjeldahl procedure adopted by the writer (7). The phosphorus determinations were performed by the writer's modification of the molybdenum blue method (5).

\section{Total phosphorus in different kind of soils}

The minimum and maximum values in Table 1 indicate a wide variation in the total phosphorus content of all the soil groups. In spite of the fact that all the ranges are overlapping each other, the mean values for the different groups of the mineral soils reflect some tendency to increase with the decrease in the dominant particle size. Both in the groups of the cultivated and virgin soils, as well as in the samples of surface layers and in the samples from deeper layers, the average content of total phosphorus in the clay soils is significantly higher than that in the sand and fine sand soils. The mean phosphorus contents of the loam and silt soils do not always significantly differ from the values for the coarser and finer soils between which they lie.

In the samples of the sand soils, fine sand soils, loam soils, and silt soils of the plough layer, the average phosphorus contents are $820 \mathrm{ppm}, 890 \mathrm{ppm}, 950 \mathrm{ppm}$, and $1050 \mathrm{ppm}$, respectively. In the deeper layers, the mean value for the loam soils is $620 \mathrm{ppm}$, and that for the silt soils is $750 \mathrm{ppm}$. Because of the low number of the samples no statistically significant difference in the phosphorus content of these adjacent soil groups may be found. Yet, a larger material could prove the existence of this trend.

In the material published by Kivinen (11) the content of phosphorus dissolved by the acid digestion appears to be higher in the clay soils than in the sand soils. The same holds true with the few samples analysed by SALONEN (13). It seems that even within the same soil the total phosphorus content is usually highest in the clay fraction and lowest in the coarse sand fraction (15).

The tendency towards a lower phosphorus content in the coarser soils could be explained by a more effective leaching of phosphorus from these soils as compared with those in which finer fractions dominate. Yet, it is not sure that this would be the right explanation. Generally, it is not likely that the leaching of phosphates from our acid soils may be marked. Besides, according to some unpublished results, the sorption of phosphorus in our soils is not correlated with their content of clay, but it seems to depend on other factors. Therefore, it is possible that it is not phosphorus which has been leached, but some other constituents which have been dissolved or dispersed during the weathering of the minerals. The mean phosphorus 
content of our granodioritic rocks is reported to be 0.11 per cent $\mathrm{P}_{2} \mathrm{O}_{5}$, or less than $500 \mathrm{ppm}$ P (13). As far as this value is reliable, it corroborates the latter supposition, or at least it indicates that phosphorus has been leached to a lower degree than is the case with some other soil constituents. AARnio (1) claims that from the plough layer of a heavy clay in Southwest Finland, 80 meters above the sea level, almost $400 \mathrm{~kg}$ of phosphorus per hectare would have been leached since its formation. In any case, this kind of estimations are connected with great errors. The present material is not large enough to permit the drawing of any reliable conclusions upon this problem, particularly, since data concerning the phosphorus content of the parent material are very scarce.

The total phosphorus content of the humus and peat soils seems to be relatively high, but attention must be paid to the fact that in these soils the weight of volume is rather low. When expressed on the volume basis, the phosphorus content of the organic soils, particularly that of the less humified peat soils, is markedly lower than that of the mineral soils: in the surface samples of the virgin peat soils the phosphorus content varies from 30 to $1100 \mathrm{~kg} / \mathrm{ha}$ in a layer of the depth of $20 \mathrm{~cm}$ while the corresponding range for the virgin sand and fine sand soils is from 900 to $2000 \mathrm{~kg} / \mathrm{ha}$.

In Table 2 the phosphorus content of the virgin peat samples are recorded according to the kind of peat. All the ranges are wide, and they overlap each other. In the surface samples the phosphorus content tends to increase with an increase in the portion of Carex-residues in the peat; only the Bryales-Carex group seems to be exceptionally low in phosphorus (cf. 7). In the samples of the deeper layers, the Carex-Sphagnum peats are fairly high in phosphorus. When the samples are divided to the old groups, Sphagnum peats and fen peats, no difference between the mean phosphorus content of the deeper layers exists, even if the exeptionally low values for the Carex-Bryales peats are excluded. In the surface layers, however, the better kind of peat contains, on the average, a statistically significantly higher amount of total phosphorus than the Sphagnum-peat group.

Table 2. Total phosphorus content in the virgin peat samples (Expressed as $\mathrm{P} \mathrm{mg} / \mathrm{kg}$ )

\begin{tabular}{|c|c|c|c|c|c|c|c|}
\hline \multirow[b]{2}{*}{ Kind of peat } & \multirow[b]{2}{*}{$\begin{array}{c}\text { Number } \\
\text { of } \\
\text { samples }\end{array}$} & \multicolumn{3}{|c|}{ Surface layer } & \multicolumn{3}{|c|}{ Deeper layers } \\
\hline & & Range & & Mean* & $\begin{array}{c}\text { Number } \\
\text { of } \\
\text { samples }\end{array}$ & Range & Mean* \\
\hline Sphagnum peat & 15 & $220-970$ & 600 & \pm 120 & 17 & $190-1180$ & $570 \pm 120$ \\
\hline Carex-Sphagnum peat & 13 & $360-1480$ & 750 & \pm 200 & 21 & $410-1810$ & $830 \pm 190$ \\
\hline Sphagnum-Carex peat & 34 & $360-1500$ & 890 & \pm 100 & 40 & $440-2050$ & $770 \pm 100$ \\
\hline Bryales-Carex peat & 9 & $340-1190$ & 640 & \pm 180 & 27 & $260-1130$ & $530 \pm 100$ \\
\hline Carex peat & 10 & $570-1480$ & 1010 & \pm 220 & 31 & $450-2350$ & $930 \pm 140$ \\
\hline Sphagnum peats & 28 & $220-1480$ & 670 & \pm 110 & 38 & $190-1810$ & $710 \pm 120$ \\
\hline Fen peats & 53 & $340-1500$ & 870 & \pm 80 & 98 & $260-2350$ & $750 \pm 220$ \\
\hline
\end{tabular}

* with the confidence limits at the 5 per cent level 
Total phosphorus in virgin and cultivated soils.

The data in Table 1 indicate that the total phosphorus content of the surface layer of the virgin soils tends to be lower than that in the plough layer of the corresponding kind of soils. In ten pairs of virgin and cultivated mineral soils sampled within a distance of not more than $50 \mathrm{~m}$, the mean content of total phosphorus were $580 \mathrm{ppm}$ in the virgin soils and $940 \mathrm{ppm}$ in the cultivated soils (9). In the deeper layers, no significant difference may be found between the phosphorus contents of the virgin and cultivated soils.

The higher content of total phosphorus in the surface layers of the cultivated soils may be accounted to the accumulation of fertilizer phosphorus. The fact must also be considered that, in the first place, soils with a higher natural fertility have been reclaimed.

\section{Total phosphorus at various depths}

In the cultivated soils the residual phosphorus of the fertilizers applied usually accumulates in the plough layer. Thus, it was found that in 35 cultivated mineral soils the total phosphorus content in the plough layer was, on the average, 1050 ppm, and in the subsoil $620 \mathrm{ppm}$, or about 60 per cent of that in the topsoil. The corresponding figures for 12 cultivated peat soils were $1130 \mathrm{ppm}$ and $920 \mathrm{ppm}$, respectively, and the phosphorus content of the subsoil corresponded to 80 per cent of that in the plough layer.

In the virgin soils the difference between the phosphorus content of the surface layer, down to about $20 \mathrm{~cm}$, and of the layer at about the depth from $20 \mathrm{~cm}$ to $40 \mathrm{~cm}$ is generally far less marked than that in the cultivated soils, since it is mostly only the effect of plant activity that may accumulate phosphorus in the surface layer. It was found that in 12 virgin mineral soils the mean phosphorus content of the surface layer was $610 \mathrm{ppm}$, and that of the deeper layer $530 \mathrm{ppm}$. In one half of the cases the surface layer contained less phosphorus than did the corresponding deeper layer. In 20 virgin peat lands the average phosphorus contents in the surface soil and in the deeper layer were $760 \mathrm{ppm}$ and $710 \mathrm{ppm}$, respectively.

It was found in a previous study (6) that in profiles of virgin peat soils some tendency exists to an increase in the phosphorus content with the increasing depth in the peat lands of a lower quality. In peat lands of a higher quality the opposite often holds true. In the present material there was a couple of profiles of virgin mineral soils. In the first of them, a silt soil, the following contents of total phosphorus in the different layers were found:

$\begin{array}{cll}0-15 \quad \mathrm{~cm} & \text { silt } & 430 \mathrm{ppm} \\ 20-30, & \text { silty clay } & 630 \\ 40-50, & \text { silt } & 550 \\ 60-70, & , & 570 \\ 200-210, & , & 640\end{array}$

In this soil the total phosphorus content was closely connected with the amount of calcium-bound phosphorus which was low in the surface soil, only $220 \mathrm{ppm}$ 
and in the deeper layers varied from $460 \mathrm{ppm}$ to $560 \mathrm{ppm}$. In a typical podsol soil, the $\mathrm{A}_{1}$ horizon contained $430 \mathrm{ppm} \mathrm{P}$, the bleached layer only $100 \mathrm{ppm}$, and all the deeper layers about 300 ppm.

The total phosphorus content at various depths of the cultivated mineral soils may be characterized by the following results which represent values for 5 sand and fine sand soils from Tohmajärvi (To), and for 5 glacial clay soils from Jokioinen $(\mathrm{J})$ :

\begin{tabular}{|c|c|c|c|c|c|c|c|c|c|c|c|}
\hline Dep & & To & 2 & To & 3 & To & 4 & To & 6 & To & 8 \\
\hline $0-10$ & $\mathrm{~cm}$ & 780 & ppm & 1170 & ppm & 710 & ppm & 1000 & ppm & 500 & ppm \\
\hline $20-30$ & , & 460 & , & 530 & , & 260 & , & 320 & , & 490 & , \\
\hline $40-50$ & , & 520 & , & 530 & . & 320 & , & 360 & , & 260 & , \\
\hline $60-70$ & , & 350 & , & 440 & , & 380 & , & 340 & , & 370 & , \\
\hline & & J & 1 & & 2 & J & 3 & J & 4 & J & 5 \\
\hline $0-10$ & $\mathrm{~cm}$ & 1310 & ppm & 1540 & ppm & 1250 & ppm & 1380 & ppm & 1200 & ppm \\
\hline $20-30$ & , & 660 & , & 730 & , & 680 & , & 830 & , & 830 & , \\
\hline $40-50$ & , & 750 & , & 710 & , & 740 & , & 730 & , & 860 & , \\
\hline $60-70$ &, & 810 & , & 770 & , & 820 & , & 790 & , & 920 & , \\
\hline
\end{tabular}

In most of these soils the upper part of the plough layer contains about twice as much phosphorus as the deeper layers. Only in the soil To 8 the equal phosphorus contents of the two top layers sampled indicates either a low application of phosphorus fertilizers, or an effective transport of fertilizer phosphorus downwards from the plough layer. In some of the soils the minimum phosphorus content may be found in the layer from $20 \mathrm{~cm}$ to $30 \mathrm{~cm}$. This could be explained by the possible uptake of phosphorus by plants also from this layer. Usually, there is no very marked variation in the phosphorus content of the deeper layers in a particular soil.

The effect of phosphorus fertilizers on the phosphorus content of a peat soil may be characterized by the following data from a field trial in which superphosphate was applied for 34 years at the rates of 0 and $200 \mathrm{~kg} / \mathrm{ha}(8)$ :

\begin{tabular}{|c|c|c|c|c|c|c|}
\hline \multirow{3}{*}{ depth } & & & \multicolumn{2}{|c|}{0} & \multicolumn{2}{|c|}{ P } \\
\hline & $0-5$ & $\mathrm{~cm}$ & 1000 & $\mathrm{pm}$ & 1470 & ppm \\
\hline & $5-10$ & , & 930 & , & 1230 & - \\
\hline & $10-15$ & , & 910 & , & 1150 & , \\
\hline & $15-20$ & , & 1000 & , & 1260 & , \\
\hline & $20-30$ & , & 1160 & , & 1340 & , \\
\hline & $30-40$ & , & 940 & , & 940 & , \\
\hline & $40-50$ & , & 840 & , & 830 & - \\
\hline & $50-60$ & , & 680 & , & 680 & , \\
\hline & $60-70$ & 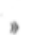 & 580 & , & 570 & , \\
\hline
\end{tabular}

During the last nine years the fertilizer was applied as a surface dressing, before that it was mixed by harrowing or ploughing. It is of interest to note that in both treatments the phosphorus content decreases from the surface layer down to the layer of 10 to $15 \mathrm{~cm}$, and then reaches a new maximum just below the plough layer 
or at the depth from 20 to $30 \mathrm{~cm}$. The effect of the application of superphosphate may be found down to this depth. It is likely that ploughing of the soil has brought the stubble partly to this layer.

\section{$S u m m$ ary}

In the present paper the total content of phosphorus in Finnish mineral soils and organic soils is discussed on the basis of data collected in connection with the writer's various works. The material consists of 670 samples which represent both the surface soils and the deeper layers.

The variation in the total phosphorus content of all the groups of soil was large with the ranges overlapping. The mean values, only, indicated some tendency to an increase in the total phosphorus content with an increase in the finer fractions in mineral soils and in the Carex-residues in the peat soils.

The effect of the application of phosphorus fertilizers is usually distinctly provable as the relatively high phosphorus content of the plough layer. The variation in the total phosphorus content within a soil profile does not show any regular trend.

\section{REFERENCES:}

(1) Aarnio, B. 1933. Die Pflanzennährstoffverhältnisse der finnischen Böden. Mezögazd. Kutátasok VI: $431-438$.

(2) - -1933 . Loimaa. Agrogeologisia karttoja No 7. Helsinki.

(3) - - 1935-38. Salo I-IV. Agrogeologisia karttoja No 8-10. Helsinki.

(4) KallA, A. 1948. Viljelysmaan orgaanisesta fosforista (On the organic phosphorus in cultivated soils.) Valt. maatal.koet. julk. 129. Helsinki.

(5) - -1955 . Studies on the colorimetric determination of phosphorus in soil extracts. Acta Agr. Fenn. 83: 25-47.

(6) - 1956. Phosphorus in various depths of some virgin peat lands. J. Sci. Agric. Soc. Finland 28: $90-104$.

(7) - - 1956. Phosphorus in virgin peat samples. Ibid. 28: 142-167.

(8) - - 1959. Effect on a peat soil of application of superphosphate at various rates. Ibid. 31: $120-130$.

(9) -1963 . Organic phosphorus in Finnish soils. Soil Sci. 95: 38-44.

(10) Krvinen, E. 1933. Suokasvien ja niiden kasvualustan kasvinravintoainesuhteista. (Untersuchungen über den Gehalt an Pflanzennährstoffen in Moorpflanzen und an ihren Standorten.) Acta Agr. Fenn. 27.

(11) - - 1934. Ưber die Pflanzennährstoffverhältnisse der Mineralböden in Finnland. J. Sci. Agric. Soc. Finland 6: 85-96.

(12) Muir, J. W. 1952. The determination of total phosphorus in soil. Analyst 77: 313-317.

(13) Salonen, M. 1941. Fosforin esiintymismuodoista Suomen maalajeissa. Acta Agr. Fenn. 48. Helsinki.

(14) Sederholm, J. J. 1925. The average composition of the earth's crust in Finland. Bull. Comm. Géol. Finlande No 70, Helsinki.

(15) Williams, E. G. \& Saunders, W. M. H. 1956. Distribution of phosphorus in profiles and particlesize fractions of some Scottish soils. J. Soil Sci. 7: $90-108$. 


\title{
SEL OST U S :
}

MAITTEMME FOSFORIN PITOISUUDESTA

\author{
Armi Kaila
}

Yliopiston maanviljelyskemian laitos, Helsinki

Tutkimuksessa on tarkasteltu maittemme fosforin kokonaismääräă käyttämällä aineistoa, joka on kerätty tekijän muiden tutkimusten yhteydessä.

Kokonaisfosforin pitoisuuden vaihtelut olivat laajat kaikissa maalajiryhmissä, ja vaihtelualueet peittivät tavallisesti toisensa. Vain ryhmien keskiarvojen perusteella voitiin todeta fosforin pitoisuuden pyrkivän nousemaan sitä mukaa kuin siirryttiin karkeista kivennäismaista savimaihin ja toisaalta rahkavaltaisista turpeista saravaltaisiin. Lannoituksen vaikutus on selvästi havaittavissa viljelysmaiden muokkauskerroksen verraten korkeina fosforin arvoina. Muuten eri kerrosten fosforin pitoisuuden vaihteluissa ei voitu havaita selvää suuntaa. 